\title{
Pathogenicity of Helminthosporium rostrata on rice varieties widely grown in Morocco
}

\author{
Nawal Imrani, Hinde Boudoudou, Afifa Mouria, Jihane Touati, Amina Ouazzani \\ Touhami, Rachid Benkirane \& Allal Douira
}

Université Ibn Tofaïl, Faculté des Sciences, Laboratoire de Botanique, Biotechnologies et Protection des Plantes, B.P. 133,

Kenitra, Morocco.

\begin{abstract}
The plants of rice varieties (Arco, Thaibonnet and Elio) were inoculated with three isolates of Helminthosporium rostrata (HR1 HR2 and HR3), isolated for the first time in Morocco from the rice seed of Taibonnet variety at the end of the growing season.

The results obtained showed that all the isolates are able to induce the disease on rice plants and sporulate on the foliar lesions. HR1, HR2 and HR3 was respectively the most pathogenic on Elio $(I . C=113)$, Arco $(I . C=212.5)$, and Taibonnet (130.48).

The symptoms induced by the isolates are similar to those induced by Helminthosporium sativum on rice.
\end{abstract}

Keywords- Rice, Helminthosporium rostrata, symptoms, pathogenicity.

\section{INTRODUCTION}

The helminthosporium disease is caused by fungi of the genus Helminthosporium. These fungi spend unfavorable season, as mycelium on infected plants and plant residues (Zambettakis, 1967; Lucas et al., 1985). The inoculum is also carried by the seeds (Wells and Winstead 1965, Wilson et al., 1993). The host range of these fungi is not limited only to the plants, particularly cereals (Paul, 1926; Serghat et al., 2005), but also extends to animals and humans (Pritchard et al., 1977).

The helminthosporium disease of rice is widespread in Moroccan rice fields. It is caused by a large number of species: Helminthosporium oryzae (Bouslim et al., 1997), H. spiciferum (Ennaffah et al., 1997), H. australiensis, $H$. sativum (Ouazzani Touhami et al., 2000), H. cynodontis (Zehhar et al., 2008) et H. bicolor (Kadri et al., 2013). Sometimes, rice foliar lesions can accommodate one or two Helminthosporium species, in addition to Pyricularia grisea, all these Helminthosporium may be encountered on the lesions of a single foot (Ouazzani Touhami et al., 2000). This involves the estimation of losses due to these pathogens and the share due to each of them (Hannin, 2003). The main thing is that each species produces sporulating lesions on rice leaves (Bahous et al., 2003).

In recent years, it was noted the presence of Helminthosporium rostrata on the rice grains harvested at the end of the vegetative cycle. This fungus has never been reported among rice mycoflora.

In this study, the symptoms of Helminthosporium rostrata are described and its pathogenicity was studied on three rice varieties.

\section{Plant materiel}

The grains of three varieties of rice plants (Arco, Thaibonnet and Elio) are disinfected by soaking in the hypochlorite of sodium in $0,6 \%$ during ten minutes, then rinsed strictly in the sterile distilled water. After $24 \mathrm{~h}$ of drying, grains are put in Petri dishes containing some sterile cotton soaked with distilled water. After $75 \mathrm{~h}$ of incubation in the darkness and in $28^{\circ} \mathrm{C}$, the obtained seedlings are planted in jars containing the soil of the forest Mamora. Then, they are watered with the tap water until the stage required for the inoculation (plant with 3 or 4 leaves).

\section{Fungal material}

The isolates of Helminthosporium rostrata (HR1, HR2 and HR3) studied are obtained from the rice grains of Taibonnet variety at the end of the growing season. These three isolates were previously transplanted from single conidia.

\section{Inoculum preparation}

$H$. rostrata isolates were pricked out on a rice flour medium (14 $\mathrm{g}$ of rice flour, $15 \mathrm{~g}$ agar-agar, $4 \mathrm{~g}$ of yeast extract and $1000 \mathrm{ml}$ of distilled water). The cultures were incubated for ten days at a temperature of $28^{\circ} \mathrm{C}$ in the dark. The surface charged with spores is scraped aseptically using a metal spatula. Conidial suspension obtained was then adjusted with sterile distilled water containing $0.05 \%$ of Tween 20 and $0.5 \%$ of gelatin, in order to have a final concentration of $10^{6}$ spores $/ \mathrm{ml}$.

\section{Inoculation and Result's evaluation}

The plants were inoculated at the stage of 4 to 5 leaves by spraying the conidial suspension above the rice leaves using a charging pulverized. The inoculated plants are placed for 48 hours under a black plastic bag to maintain a high relative humidity. Control plants are sprayed with sterile distilled water containing $0.05 \%$ of Tween 20 and $0.5 \%$ of gelatin. The inoculated and control plants are 
then placed in the greenhouse for development of symptoms. Seven days after inoculation, the disease severity (S) is estimated using the scale of Notteghem et al. (1980), the disease incidence (I) represents the number of infected leaves. The infection coefficient (I.C) is calculated by multiplying I x S.

The disease severity index is determined by the percentage of the diseased leaf area estimated by the rating scale Notteghem et al. (1980).

\begin{tabular}{|l|c|c|c|c|c|c|c|c|c|c|}
\hline Note & 0 & 1 & 2 & 3 & 4 & 5 & 6 & 7 & 8 & 9 \\
\hline $\begin{array}{c}\text { diseased } \\
\text { leaf } \\
\text { area }\end{array}$ & 0 & 0.05 & 0.5 & 1.5 & 3.5 & 7.5 & 17.5 & 37.5 & 62.5 & 87.5 \\
\hline
\end{tabular}

The statistical treatment of data focused on the variance analysis and p.p.d.s test at the threshold of 5\%.

\section{Sporulation on the host}

Sporulation on host is estimated by the method of Hill and Nelson (1983) by counting the average number of spores produced per unit area of the host leaves carrying lesions (number of spores / $\mathrm{ml}$ ).

Ten days after inoculation, leaves showing lesions are taken from inoculated plants of rice, cut into pieces of 1 $\mathrm{cm}$ and then placed in Petri plates containing two discs of filter paper soaked with sterile distilled water (1 leaf per plate). The plates are placed at $30 \mathrm{~cm}$ in continues light to $28^{\circ} \mathrm{C}$.

After $48 \mathrm{~h}$, the fragments of each leaf were placed in a test tube containing $1 \mathrm{ml}$ of sterile distilled water and stirred by vortexing for 2 minutes in order to detach the conidia from the mycelium.
The spore's number in the suspension was determined using a Malassez blade (10 counts per sample). The observation is made at magnification factor $\mathrm{x} 100$.

\section{RESULTS}

The leaves of rice three varieties, inoculated with $H$. rostrata, have tapered brown spots, and in the center, a dark brown aureole corresponding to the fungus penetration area on the leaves. Lesion size is variable and may be up to $5 \mathrm{~mm}$ length on certain varieties (Arco) (Figure 1).

The results of table 1 indicate that $H$. rostrata isolates showed pathogenicity, as estimated by the infection coefficient, varying depending on the tested rice varieties ; HR1, HR2 and HR3 was respectively the most pathogenic on Elio (I.C = 113), Arco (I.C = 212.5), and Taibonnet $(130,48)$.

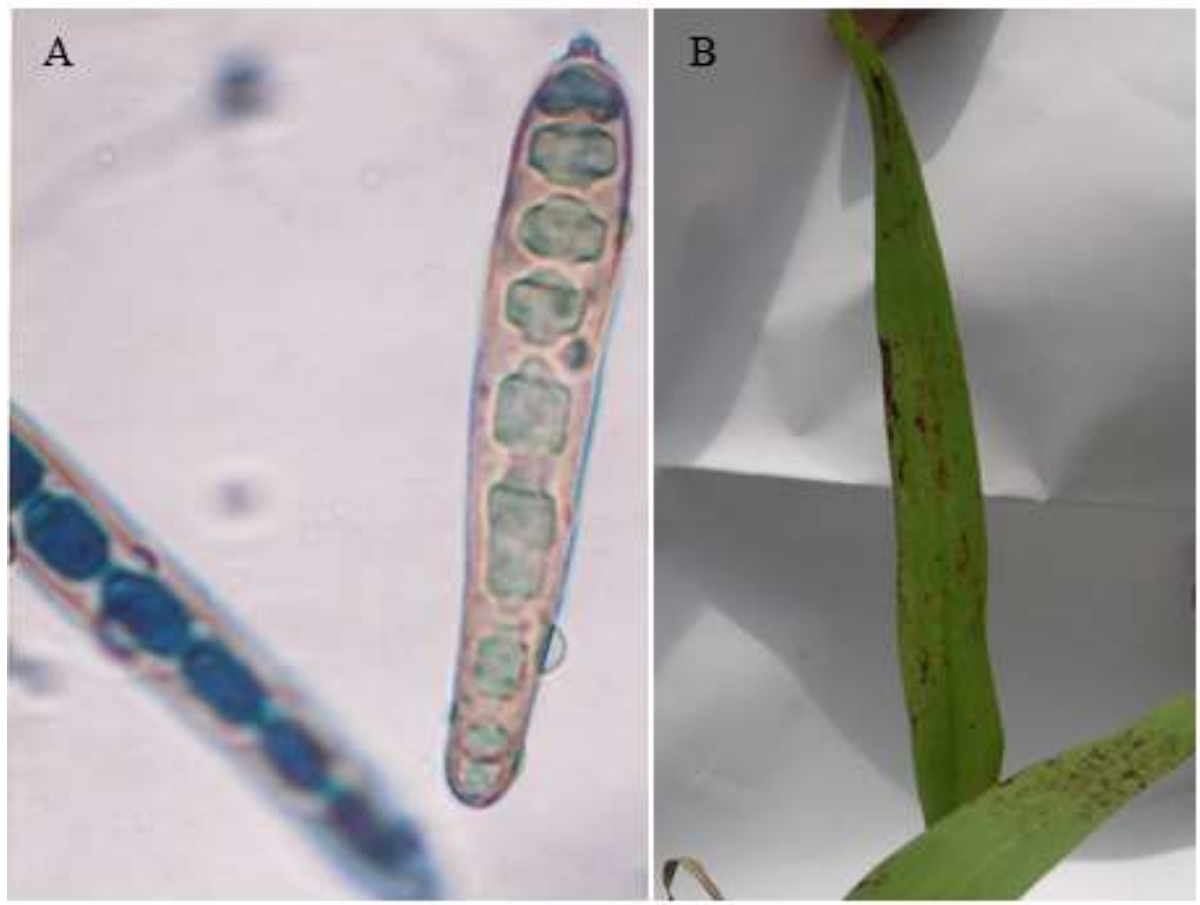

Fig.1: Helminthosporium rostrata : Conidia $(A)$ and symptoms on rice leaves $(B)$ 
Table.1: disease Incidence, severity and infection coefficient of rice varieties inoculated with $H$. rostrata isolates.

\begin{tabular}{|c|c|c|c|c|c|c|c|c|c|c|}
\hline \multicolumn{2}{|c|}{} & \multicolumn{9}{c|}{ Varieties } \\
\hline \multirow{2}{*}{ Isolates } & \multicolumn{3}{c|}{ Arco } & \multicolumn{3}{c|}{ Taibonnet } & \multicolumn{3}{c|}{ Elio } \\
\cline { 3 - 12 } & I & S & I.C & I & S & I.C & I & S & I.C \\
\hline \multirow{3}{*}{$\begin{array}{c}\text { Helminthosporium } \\
\text { rostrata }\end{array}$} & HR2 & 19 & 6.1 & $212.5^{\mathrm{a}}$ & 25 & 4.8 & $120^{\mathrm{b}}$ & 23 & 5.67 & $84.66^{\mathrm{b}}$ \\
\cline { 2 - 13 } & $\mathbf{H R 3}$ & 17 & 6.68 & $82.61^{\mathrm{c}}$ & 20 & 4.23 & $130.48^{\mathrm{a}}$ & 15 & 5.37 & $80.6^{\mathrm{b}}$ \\
\cline { 2 - 13 }
\end{tabular}

Two results on the same column differ significantly at $5 \%$ level (p.p.d.s test) if they are not assigned by any letter in common, insignificant in the contrary case.

The results given in Table 2 show that all fungal species tested are able to sporulate on the leaves of rice varieties. Sporulation of HR2 isolate is very important on the three varieties. It is in the order of $17.3310^{5}$ conidia $/ \mathrm{cm}^{2}$ on
Arco, $15.3310^{5} / \mathrm{cm}^{2}$ on Taibonnet and $13.3310^{5}$ conidia/ $\mathrm{cm}^{2}$ on Elio. The isolate HR1 sporulates well on Arco variety $\left(1710^{5}\right.$ conidia $\left./ \mathrm{cm}^{2}\right)$, however sporulation is about $11.6610^{5}$ conidia $/ \mathrm{cm}^{2}$ on Taibonnet and decreases in the variety Elio $\left(910^{5}\right.$ conidia $\left./ \mathrm{cm}^{2}\right)$.

The isolate HR3 sporulates less on Arco varieties (2.33 $10^{5}$ conidia $\left./ \mathrm{cm}^{2}\right)$ and Elio $\left(4.3310^{5}\right.$ conidia $\left./ \mathrm{cm}^{2}\right)$.

Table.2: Sporulation of Helminthosporium rostrata isolates on rice varieties $\left(10^{5}\right.$ conidia/ $\left.\mathrm{cm}^{2}\right)$

\begin{tabular}{|c|c|c|c|}
\hline & \multicolumn{3}{|c|}{ Isolates sporulation $\left(10^{5}\right.$ conidia/cm $\left.{ }^{2}\right)$} \\
\hline Varieties & HR1 & HR2 & HR3 \\
\hline Arco & $17.00^{\mathrm{a}}$ & $17.33^{\mathrm{a}}$ & $2.33^{\mathrm{ab}}$ \\
\hline Taibonnet & $11.66^{\mathrm{b}}$ & $15.33^{\mathrm{a}}$ & $10.00^{\mathrm{b}}$ \\
\hline Elio & $9,00^{\mathrm{b}}$ & $13.33^{\mathrm{a}}$ & $4.33^{\mathrm{c}}$ \\
\hline
\end{tabular}

Two results on the same column differ significantly at $5 \%$ level (p.p.d.s test) if they are not assigned by any letter in common, insignificant in the contrary case.

\section{DISCUSSION \& CONCLUSION}

The results obtained showed that $H$. rostrata, represented by the three isolates tested, is capable of altering the rice plants foliage. This pathogen encountered for the first time on the rice grains of Taibonnet variety, can induce the disease on the leaves of other varieties of rice (Arco and Elio).

Symptoms developed on the rice plants leaves varies from variety to another. They are similar morphologically to those induced by Helminthosporium sativum on Rice (Ouazzani et al., 2000), but different from those caused by $H$. oryzae (Bouslim et al., 1997), H. spiciferum (Ennaffah et al. 1997), H. australiensis (Ouazzani et al., 2000) and H. bicolor (Leopold, 2005).

All developed leaf lesions are sporulating, that is to say, that $H$. rostrata is capable, once inoculated to the rice plants leaves to produce secondary inoculum that can infect other healthy rice leaves and therefore to participate in the progression of the disease.

All these observations allow to incriminate $H$. rostrata, isolated from seeds, as a new rice leaf pathogen.
The introduction of some sensitive varieties, case of Arco variety, will favor the multiplication of this pathogen which probably finds in the Moroccan rice all favorable conditions for its development.

Furthermore, on other host plants, $H$. rostrata attack all aerial parts of corn plant, sorghum, and some plants such as pearled millet, which is an annual herb of the hot season (Mathur et al., 1973).

But according to some authors (Kadir and Ahmed, 2004), $H$. rostrata is unable to attack the bean. These authors suggested introducing in rotation this plant species to reduce the inoculum of this pathogen.

\section{REFERENCES}

[1] Bahous M, Ouazzani Touhami A. \& Douira A. 2003. Interaction between Pyricularia oryzae, four Helminthosporium species and Curvularia lunata in rice leaves. Phytopathol. Mediterr., 42: 133-142.

[2] Bahous M. 2006. Contribution à l'étude de l'écologie de différents champignons sur les feuilles du riz (Oryza sativa L.). Mesures de lutte chimique par l'azoxystrobine. Thèse de Doctorat, Université Ibn Tofail, Fac. des Sciences, Kénitra, Maroc, p. 158. 
[3] Bahous M., Ouazzani Touhami A. \& Douira A. 2008. Survie de quelques agents pathogènes de riz au laboratoire. Bulletin de l'Institut Scientifique, Rabat, section Sciences de la Vie, 30: 13- 18.

Bouslim F., Ennaffah B., Ouazzani Touhami A., Douira A \& El Haloui N.E. 1997. Pathogénie comparée de quelques isolats marocains d'Helminthosporium oryzae vis-à-vis de certaines variétés de riz (Oryza sativa). Al Awamia, 10 : 9-18.

[4] Ennaffah B., Bouslim F., Benkirane R., Ouazzani Touhami A. \& Douira A., 1997. Helminthosporium spiciferum, foliar parasite of rice in morocco. Agronomie, 17: 299-300.

[5] Gnancadja-André L.S., 2005. Etude de la mycoflore et du développement de la Ternissure des grains du riz (Orysa sativa) au Maroc. Biologie et pouvoir pathogène de Helminthosporium bicolor, originaire de Stenotaphrum secundatum. Thèse de Doctorat, Université Ibn Tofail, Fac. des Sciences, Kénitra, Maroc, 206p.

[6] Hannin S., 2003. Etude de la mycoflore du riz (Oryza sativa): Impact et moyens de lutte. Thèse de Doctorat, Univ. Ibn Tofail, Fac. Sciences, Kénitra, Maroc, $108 \mathrm{p}$.

[7] Hill J.P. \& Nelson R.R., 1983. Genetic control of two parasitic fitness attributes of Helminthosporium maydis race T. Phytopathology, 73(3): 455-457.

[8] Kadir J. \& Ahmad A., 2004. Potential of Drechslera longirostrata as bioherbicide for itch grass. Department of Plant Protection, University Putra Malaysia, 43400 UPM, Serdang, Selangor, Malaysia.

[9] Kadri O., Simplice Léopold Gnancadja-Andre S.L., Chliyeh M., Ouazzani Touhami A., \& Douira A., 2013. Helminthosporium bicolor, un pathogène foliaire du riz et de Stenotaphrum secundatum au Maroc. Int. J. Biol. Chem. Sci. 7(1): 332-337.

[10] Lucas G. B., Campbell C.L. \& Lucas L.T., 1985. Introduction to plant diseases. Identification and management. Department of plant pathology North Carolina state. University Realeigh. Blast of Rice, p: 189-191.

[11] Mathur, S.K., Nath R., \& Mathur S.B., 1973. Seed-borne fungi of pearl millet (Pennisetum typhoides) and their significance. Seed Science Technology, 1: 811-820.

[12] Notteghem J.L., Andriatompo G.M., Chatel M. \& Dechanet R., 1980. Techniques utilisées pour la sélection des variétés de riz possédant la résistance horizontale à la pyriculariose. Ann. Phytopathol., 12(3) : 199-226.
[13] Ouazzani Touhami A., Ennaffah B, El Yachioui M \&, Douira A., 2000. Pathogénie comparée de quatre espèces d'Helminthosporium obtenues à partir des plantes malades du Riz au Maroc. J .Phytopathol., 148: 221-226.

[14] Paul A.Y., 1926. Facultative Parasitism and Host Ranges of Fungi. American Journal of Botany, 13(8): 502-520.

[15] Pritchard D., Chick B.F. \& Connole M.D., 1977. Eumycotic mycetoma due to Drechslera rostrata infection in a cow. PubMed. 53(5): 241-244.

[16] Serghat S, Ouazzani Touhami A. \& Douira A., 2005. Pathogénie d'Helminthosporium oryzae vis-àvis de quelques graminées cultivées au Maroc. Cah. Rech. Université Hassan II, série A (Sciences et Techniques), 6: 1-11.

[17] Wilson J.P., Hanna W.W., Wilson D.M., Beaver R.W. \& Casper H.H., 1993. Fungal and mycotoxin contamination of pearl millet grain in response to environmental conditions in Georgia. Plant Disease, 77:121-124

[18] Wells H.D. \& Winstead E.E., 1965. Seed-borne fungi in Georgia-grown and western-grown pearl millet seed on sale in Georgia during 1960. Plant Disease Reporter, 49:487-489.

[19] Zambettakis C.H., 1967. Helminthosporium oryzae Breda de Haan. Helminthosporiose du riz. Fiches de phytopathologie Tropicale. Revue de Mycologie, Tome XXXII, Fascicule 3, N²1.

[20]Zehhar G., Ouazzani Touhami A. \& Douira A., 2008. First report of Bipolaris cynodontis on Oryza sativa in Morocco. Phytopathol. Mediterr., 47: 7376 